\title{
Concentrations and fluxes of biogenic volatile organic compounds above a Mediterranean macchia ecosystem in western Italy
}

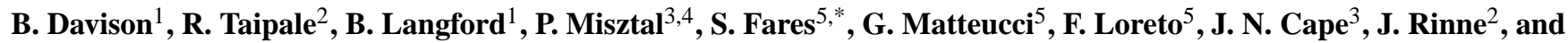 \\ C. N. Hewitt ${ }^{1}$ \\ ${ }^{1}$ Lancaster Environment Centre, Lancaster University, Lancaster LA1 4YQ, UK \\ ${ }^{2}$ University of Helsinki, Department of Physics, P.O. Box 64, 00014 University of Helsinki, Finland \\ ${ }^{3}$ Centre for Ecology \& Hydrology, Bush Estate, Penicuik, Midlothian EH26 0QB, UK \\ ${ }^{4}$ School of Chemistry, University of Edinburgh, Edinburgh EH9 3JJ, UK \\ ${ }^{5}$ National Research Council, Institute of Agro-environmental and Forest Biology, Via Salaria km. 29300, \\ 00016 Monterotondo Scalo, Rome, Italy \\ * now at: University of California, Department of Environmental Science, Policy, and Management, 137 Mulford Hall, \\ Berkeley, CA 94720, USA
}

Received: 21 November 2008 - Published in Biogeosciences Discuss.: 23 February 2009

Revised: 24 June 2009 - Accepted: 26 June 2009 - Published: 14 August 2009

\begin{abstract}
Emission rates and concentrations of biogenic volatile organic compounds (BVOCs) were measured at a Mediterranean coastal site at Castelporziano, approximately $25 \mathrm{~km}$ south-west of Rome, between 7 May and 3 June 2007, as part of the ACCENT-VOCBAS field campaign on biosphere-atmosphere interactions. Concentrations and emission rates were measured using the disjunct eddy covariance (DEC) method utilizing three different proton transfer reaction mass spectrometers (PTR-MS) so allowing a comparison between the instruments. The high resolution data from the PTR-MS instruments considerably enhances the original BEMA measurements of the mid 1990s.

Depending on the measurement period, the volume mixing ratios were in the range 1.6-3.5 ppbv for methanol, 0.44 $1.3 \mathrm{ppbv}$ for acetaldehyde, $0.96-2.1 \mathrm{ppbv}$ for acetone, 0.10 $0.14 \mathrm{ppbv}$ for isoprene, and $0.13-0.30 \mathrm{ppbv}$ for monoterpenes. A diurnal cycle in mixing ratios was apparent with daytime maxima for methanol, acetaldehyde, acetone, and isoprene. The fluxes ranged from $370-440 \mu \mathrm{g} \mathrm{m}^{-2} \mathrm{~h}^{-1}$ for methanol, $180-360 \mu \mathrm{g} \mathrm{m}^{-2} \mathrm{~h}^{-1}$ for acetaldehyde, 180 $450 \mu \mathrm{g} \mathrm{m}^{-2} \mathrm{~h}^{-1}$ for acetone, $71-290 \mu \mathrm{g} \mathrm{m}^{-2} \mathrm{~h}^{-1}$ for isoprene, and $240-860 \mu \mathrm{g} \mathrm{m}^{-2} \mathrm{~h}^{-1}$ for monoterpenes. From the measured flux data (7 May-3 June) an average basal emission rate for the Macchia vegetation was calculated
\end{abstract}

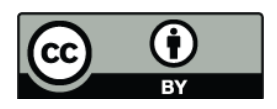

Correspondence to: B. Davison (b.davison@lancaster.ac.uk) of $430 \mu \mathrm{g} \mathrm{m}^{-2} \mathrm{~h}^{-1}$ for isoprene and $1100 \mu \mathrm{g} \mathrm{m}^{-2} \mathrm{~h}^{-1}$ for monoterpenes.

\section{Introduction}

Emissions of biogenic volatile organic compounds (BVOCs) play an important role in atmospheric chemistry. Oxidation of VOCs (both biogenic and anthropogenic) in a $\mathrm{NO}_{x}$-rich atmosphere may lead to the production of tropospheric ozone, which has impacts on human health and can cause damage to crops, forest ecosystems, and buildings (e.g. Sillman et al., 1999; Fowler et al., 2008).

In Mediterranean areas, where both emission and oxidation rates of BVOCs are high, production of ozone and particles from BVOC precursors represent a significant air quality challenge. Previous measurements have shown that isoprene and monoterpenes form the bulk of the total BVOC emissions from Mediterranean type ecosystems (Helmig et al., 1999). However, little is known about emissions of oxygenated compounds, such as methanol and acetone, from these ecosystems. Emissions of isoprene and monoterpenes are strongly regulated by variations in light and temperature (e.g., Guenther et al., 1993). Nonetheless, the light and temperature dependent emission algorithms are still limited by uncertainties, particularly of the basal emission rates on which they depend. 
To better understand the processes controlling photochemical pollution episodes, regional and global scale BVOC emission models have been developed. Until recently, many model estimates for biogenic emissions from Mediterranean type ecosystems (Guenther et al., 1995; Simpson et al., 1999), which could include regions of Chile, California, South Africa, Australia, and Europe, were calculated using basal emission rates determined for Californian Mediterranean type ecosystems only (Owen et al., 1997). However isoprene and monoterpene emissions both tend to be very species specific, which generates considerable uncertainty in the model.

In recent years, efforts have been made to determine emission rates for a number of Mediterranean type ecosystems. In Europe, BVOC emissions in the Mediterranean area were extensively studied as part of the Biogenic Emissions in the Mediterranean Area (BEMA) project (Bertin et al., 1997; Ciccioli et al., 1997; Kesselmeier et al., 1997; Owen et al., 1997, 2001, 2002; Seufert et al., 1997; Street et al., 1997; Valentini et al., 1997). The BEMA project focused on emissions from the Castelporziano nature reserve near Rome, Italy. As the site comprised a number of vegetation types, both species specific and averaged ecosystem (forest, pseudosteppe, or macchia) emission rates could be calculated, which allowed improved modelled BVOC emission estimates within this region.

Since the BEMA campaigns there have been improvements in analytical techniques for VOCs. The advent of proton transfer reaction mass spectrometry (PTR-MS) has allowed online VOC measurements at ambient mixing ratio levels (e.g., Hansel et al., 1995; Lindinger et al., 1998; de Gouw and Warneke, 2007; Hayward et al., 2004; Tani et al., 2003; Hewitt et al., 2003). The ability of the PTR-MS to measure VOC mixing ratios at the pptv (parts per trillion by volume) level with a response time of a second or less has enabled the use of the PTR-MS instrument in micrometeorological flux measurement methods such as disjunct eddy covariance (DEC) (Rinne et al., 2001; Karl et al., 2002).

This paper presents the results of the mixing ratio and flux measurements made at Castelporziano within the frame of the ACCENT-VOCBAS campaign on biosphere-atmosphere interactions (for an overview, see Fares et al., 2009).

The determination of ecosystem scale emission potentials for terpenoids from species diverse ecosystems, such as Macchia, using species specific leaf level measurements is challenging. Thus micrometeorological flux measurement techniques can be very useful as ecosystem scale emission potentials can be derived directly using these measurements (e.g. Rinne et al., 2001). One specific aim of this study is to derive the terpenoid emission potentials for the Macchia and compare them with the ones derived by leaf level measurements.

The measurements conducted in many ecosystems have shown considerable emissions of non-terpenoid VOCs, such as methanol and acetone. However, our knowledge on the emission of these compounds from many ecosystems and re- gions is still far from complete. The second major aim of this study is to quantify the emissions of non-terpenoid VOC emissions in relation to terpenoid emissions.

\section{Methods}

\subsection{Measurement site}

The Presidential Estate of Castelporziano ( $41^{\circ} 40^{\prime} 49^{\prime \prime} \mathrm{N}, 12^{\circ}$ $23^{\prime} 31^{\prime \prime} \mathrm{E}$ ) is located about $25 \mathrm{~km}$ to the south-west from the city centre of Rome, Italy. It covers an area of $60 \mathrm{~km}^{2}$ and has a coastline of $5 \mathrm{~km}$ (for a detailed description of the site and the reason for its choice see Fares et al., 2009). Due to restricted public access, a number of Mediterranean ecosystem types have been preserved (e.g., macchia and pseudosteppe). The estate has few roads and low traffic but is bounded on its north-west by the busy Ostia-Rome commuter road. The smaller SS601 public road transects the southern edge creating a boundary between the high and low macchia. The low macchia was chosen as the site for this study.

A measurement tower was erected in a slight valley depression separated from the sea by two lines of sand dunes. The vegetation in the vicinity of the tower consisted mainly of Arbutus unedo, Rosmarinus officinalis, Quercus ilex, Phillyrea angustifolia, and Erica multiflora (Fares et al., 2009). The average canopy height, $1.2 \mathrm{~m}$, was estimated by calculating the weighted average of the average heights of these main species, which covered $80 \%$ of the total area of $1070 \mathrm{~m}^{2}$ around the tower. The weight factor was the proportion of the total area covered by a particular species. A forest of $23 \mathrm{~km}^{2}$ dominated by Holm oak (Quercus ilex) was located approximately $1 \mathrm{~km}$ to the north-east (Seufert et al., 1997).

\subsection{Measurement setup and procedure}

Commercial PTR-MS instruments (Ionicon Analytik GmbH) were used in the measurements. Lancaster University (LU) and the National Research Council and University of Helsinki (CNR-UH) used two instruments which both featured two turbomolecular pumps, a heated silica steel inlet system, and a $9.6 \mathrm{~cm}$ long stainless steel drift tube. According to the manufacturer, the response time was about $1 \mathrm{~s}$ for these instruments. The PTR-MS used by the Centre for Ecology \& Hydrology (CEH) contained a third turbomolecular pump and its response time was about $0.2 \mathrm{~s}$.

Each group used its own measurements regime so allowing the opportunity to compare these. The measurement setup used by LU and CEH during the first measurement period consisted of a three-dimensional ultrasonic anemometer (Gill Instruments Ltd., Solent R2), and two PTR-MS instruments. LU also used a humidity sensor (Honeywell International, Inc., HIH-4000-001) and an ozone monitor (2B Technologies, Inc., 205 dual beam). The anemometer was mounted 
Table 1. PTR-MS measurement cycles, the compounds contributing to the measured masses, and the PTR-MS integration, or dwell, times. For LU and CEH the cycle length was $1.4 \mathrm{~s}$ in the micrometeorological flux measurements (A) and $7.1 \mathrm{~s}$ in the ambient mixing ratio measurements (B). For CNR-UH the cycle lengths were 13.3 and 37.5 s, respectively.

\begin{tabular}{|c|c|c|c|c|c|c|}
\hline \multicolumn{2}{|c|}{ Protonated mass [amu] and contributing compound(s) } & \multicolumn{2}{|l|}{ Formula } & \multicolumn{2}{|c|}{ Dwell time [s] } & \\
\hline & & \multicolumn{2}{|c|}{$\mathrm{LU}$ and $\mathrm{CEH}$} & \multicolumn{2}{|c|}{ CNR-UH } & \\
\hline & & A & B & A & B & \\
\hline 21 & water isotope & $\mathrm{H}_{2}^{18} \mathrm{O}$ & 0.1 & 0.1 & 0.1 & 0.1 \\
\hline 33 & methanol & $\mathrm{CH}_{4} \mathrm{O}$ & 0.2 & - & 1.0 & 2.0 \\
\hline 37 & water cluster & $\left(\mathrm{H}_{2} \mathrm{O}\right)_{2}$ & - & - & 0.1 & - \\
\hline 39 & water cluster isotope & $\mathrm{H}_{2} \mathrm{OH}_{2}^{18} \mathrm{O}$ & 0.1 & - & - & 0.1 \\
\hline 42 & acetonitrile & $\mathrm{C}_{2} \mathrm{H}_{3} \mathrm{~N}$ & - & - & - & 2.0 \\
\hline 45 & acetaldehyde & $\mathrm{C}_{2} \mathrm{H}_{4} \mathrm{O}$ & 0.2 & - & 1.0 & 2.0 \\
\hline 55 & water cluster & $\left(\mathrm{H}_{2} \mathrm{O}\right)_{3}$ & - & - & 0.1 & 0.1 \\
\hline 59 & acetone & $\mathrm{C}_{3} \mathrm{H}_{6} \mathrm{O}$ & 0.2 & - & 1.0 & 2.0 \\
\hline 63 & dimethylsulfide & $\mathrm{C}_{2} \mathrm{H}_{6} \mathrm{~S}$ & - & 1.0 & - & 2.0 \\
\hline \multirow[t]{2}{*}{69} & isoprene & $\mathrm{C}_{5} \mathrm{H}_{8}$ & 0.2 & - & 1.0 & 2.0 \\
\hline & $\begin{array}{l}\text { methylbutenol frag- } \\
\text { ment }\end{array}$ & & & & & \\
\hline \multirow[t]{2}{*}{71} & methacrolein & $\mathrm{C}_{4} \mathrm{H}_{6} \mathrm{O}$ & - & - & 1.0 & 2.0 \\
\hline & methyl vinyl ketone & $\mathrm{C}_{4} \mathrm{H}_{6} \mathrm{O}$ & & & & \\
\hline 73 & methyl ethyl ketone & $\mathrm{C}_{4} \mathrm{H} 8 \mathrm{O}$ & - & 1.0 & - & - \\
\hline 77 & $\begin{array}{l}\text { peroxyacetyl nitrate } \\
\text { fragment }\end{array}$ & $\mathrm{C}_{2} \mathrm{H}_{3} \mathrm{NO}_{5}$ & - & 1.0 & - & - \\
\hline 79 & benzene & $\mathrm{C}_{6} \mathrm{H}_{6}$ & - & 1.0 & - & 2.0 \\
\hline \multirow[t]{2}{*}{81} & $\begin{array}{l}\text { monoterpene frag- } \\
\text { ments }\end{array}$ & & 0.2 & - & 1.0 & 2.0 \\
\hline & hexenal fragment & & & & & \\
\hline 83 & $\begin{array}{l}\text { cis-3-hexenol fragment } \\
\text { hexanal fragment }\end{array}$ & & - & - & 1.0 & 2.0 \\
\hline 87 & methylbutenol & $\mathrm{C}_{5} \mathrm{H}_{10} \mathrm{O}$ & - & - & 1.0 & 2.0 \\
\hline 93 & toluene & $\mathrm{C}_{7} \mathrm{H}_{8}$ & - & 1.0 & - & 2.0 \\
\hline 99 & hexenal & $\mathrm{C}_{6} \mathrm{H}_{10} \mathrm{O}$ & - & - & 1.0 & 2.0 \\
\hline \multirow[t]{2}{*}{101} & cis-3-hexenol & $\mathrm{C}_{6} \mathrm{H}_{12} \mathrm{O}$ & - & - & 1.0 & 2.0 \\
\hline & hexanal & $\mathrm{C}_{6} \mathrm{H}_{12} \mathrm{O}$ & & & & \\
\hline 107 & xylenes & $\mathrm{C}_{8} \mathrm{H}_{10}$ & - & 1.0 & - & 2.0 \\
\hline 113 & & & - & - & 1.0 & 2.0 \\
\hline 121 & $\mathrm{C}_{9}$ aromatics & & - & 1.0 & - & - \\
\hline 137 & monoterpenes & $\mathrm{C}_{10} \mathrm{H}_{16}$ & 0.2 & - & 1.0 & 2.0 \\
\hline 157 & & & - & - & - & 2.0 \\
\hline
\end{tabular}

at $5 \mathrm{~m}$ above ground on the south-west corner of the measurement tower. This position gave a fetch of approximately $300 \mathrm{~m}$ to the north-west, more than $500 \mathrm{~m}$ to the south-east, but less than $60 \mathrm{~m}$ in the two major wind directions (southwest and north-east). The analytical instrumentation was housed in an air-conditioned cabin $10 \mathrm{~m}$ to the south-east of the tower. A $20 \mathrm{~m}$ length of $3 / 8$ inch Teflon tube, heated to avoid condensation was used as the main sampling line taking air at $181 \mathrm{~min}^{-1}$ from a position $30 \mathrm{~cm}$ below the anemometer.

The PTR-MS instruments sampled from the main sampling line at $0.251 \mathrm{~min}^{-1}$. They were optimised to an $E / N$ ratio of $128 \mathrm{Td}$ using a drift tube pressure, temperature, and voltage of $2.02 \mathrm{hPa}, 45^{\circ} \mathrm{C}$, and $500 \mathrm{~V}$, respectively. The reaction time was $100 \mu$ s and the count rate of $\mathrm{H}_{3} \mathrm{O}^{+} \mathrm{H}_{2} \mathrm{O}$ ions was $1.2-2.6 \%$ of the count rate of $\mathrm{H}_{3} \mathrm{O}^{+}$ions, which was $(1.6-3.1) \times 10^{6}$ counts $^{-1}$. The data from the ultrasonic anemometer and PTR-MS were logged into the same computer using a programme written in LabView (National Instruments Corp.). The humidity sensor and ozone monitor sampled from the main line at a rate of $0.5 \mathrm{~Hz}$ and ancillary measurements of air pressure, temperature, photosynthetically active radiation, and $\mathrm{CO}_{2}$ and $\mathrm{H}_{2} \mathrm{O}$ mixing ratios were recorded by an environmental gas analyser (PP Systems, EGM-4) with a time resolution of $20 \mathrm{~s}$. 
Both PTR-MS instruments measured in three modes: flux, ambient mixing ratio, and zero air. Each instrument measured zero air for a 5-min period each hour followed by a 25min flux measurement period and then a 5-min mixing ratio measurement period before a second 25-min flux measurement period. Zero air was generated by passing ambient air through a glass tube containing a platinum catalyst powder at $0.51 \mathrm{~min}^{-1}$. In the flux measurements, the PTR-MS measurement cycle contained eight masses, of which six were related to BVOCs (Table 1). The PTR-MS integration, or dwell, time was $0.2 \mathrm{~s}$ for each BVOC-related mass and the total measurement cycle length was $1.4 \mathrm{~s}$. This corresponded to approximately 1070 measurements over the 25 -min flux averaging period. In the ambient mixing ratio measurements, seven BVOC-related masses were measured within a PTRMS measurements cycle of $7.1 \mathrm{~s}$ (Table 1) with an integration time of $1 \mathrm{~s}$ for each VOC-related mass.

The measurement setup of CNR-UH during the second measurement period consisted of a three-dimensional ultrasonic anemometer (R. M. Young Company, model 81000) and a PTR-MS. As in the setup of LU and CEH, the anemometer and the inlet of the main sampling line were attached to the measurement tower at $5 \mathrm{~m}$ above ground and the PTR-MS was housed in the air-conditioned cabin. The main sampling line, unheated was $25 \mathrm{~m}$ long, its inner diameter was $8 \mathrm{~mm}$, and it was made of Teflon (PTFE). Previous test had shown line losses to be minimal provided no condensation was in the line. As the building housing the PTR-MS was warmer than outside, despite air conditioning condensation was considered unlikely. A continuous flow of $251 \mathrm{~min}^{-1}$ was used in the main line and a side flow of $0.121 \mathrm{~min}^{-1}$ was taken into the PTR-MS via a $1.5 \mathrm{~m}$ long PTFE tube, which had an inner diameter of $1.6 \mathrm{~mm}$. A PTFE filter ( $1 \mu \mathrm{m}$ pore size, LI-COR, Inc., part number 9967-008) was installed in front of the PTR-MS inlet to prevent particles from entering the instrument.

The operating parameters of the PTR-MS were held constant during the measurement period (20 May-3 June), except for the secondary electron multiplier voltage, which was optimized before every calibration. The drift tube pressure, temperature, and voltage were $2.2 \mathrm{hPa}, 55^{\circ} \mathrm{C}$, and $600 \mathrm{~V}$, respectively. The parameter $E / N$ was about $130 \mathrm{Td}$ and the reaction time was about $97 \mu \mathrm{s}$. The count rate of $\mathrm{H}_{3} \mathrm{O}^{+} \mathrm{H}_{2} \mathrm{O}$ ions was $1-9 \%$ of the count rate of $\mathrm{H}_{3} \mathrm{O}^{+}$ions, which was $(2.9-5.5) \times 10^{6}$ counts $^{-1}$.

The wind measurements were conducted continuously at a sampling frequency of $20 \mathrm{~Hz}$ and the data were recorded on a different computer than the BVOC data. The BVOC measurement procedure was controlled with the Balzers Quadstar 422 software of the PTR-MS and it contained two hourlong sequences. Every second hour was allocated to the flux measurements. The PTR-MS measurement cycle consisted of 15 masses of which 12 were related to BVOCs (Table 1). The measurement cycle length was $13.3 \mathrm{~s}$ and the cycle was repeated 264 times an hour. The PTR-MS integration time was $1 \mathrm{~s}$ for each BVOC-related mass. The other hour-long sequence consisted of zero air measurements and ambient mixing ratio measurements. In the zero air measurements, VOC-free air produced from ambient air with a zero air generator (catalytic converter, Parker Hannifin Corp., ChromGas Zero Air Generator 1001) was fed into the PTR-MS to determine BVOC background signals of the instrument. Zero air was measured for about 12.5 min (20 cycles) and then the PTR-MS was set to measure ambient air for about $37.5 \mathrm{~min}$ (60 cycles). In both measurements, the PTR-MS measurement cycle contained 21 masses, 18 of which were related to BVOCs (Table 1). The measurement cycle length was $37.5 \mathrm{~s}$ and the integration time was $2 \mathrm{~s}$ for each VOC-related mass. The last $10 \mathrm{~min}$ of the sequence were allocated to mass scan measurements of ambient air. The scan range was 40$250 \mathrm{amu}$ and the integration time was $2 \mathrm{~s}$ for each mass.

\subsection{Calculation of BVOC volume mixing ratios}

The PTR-MS instruments of LU and CEH were calibrated against the same gas standard, which contained methanol, acetaldehyde and acetone at a mixing ratio of 1 ppmv. The gas standard was prepared by diluting known volumes of the gas standard with zero hydrocarbon free air in Tedlar bags. These were then used to calibrate the PTR-MS over the range of 2-700 ppbv. In the first period, BVOC calibrations were done on 6 and 13 May.

LU and CEH calculated the normalized sensitivities for isoprene and monoterpenes (Table 2) using the proton transfer reaction rate coefficients of Zhao and Zhang (2004) and the instrument specific transmission coefficients which were calculated following the procedure described by Wilkinson (2006).

The PTR-MS of CNR-UH was calibrated three times during the measurement period: on 20, 25, and 31 May. These calibrations were performed with gas standards prepared by diluting pure liquid standards in nitrogen and analysed with a gas chromatograph-mass spectrometer at CNR. The monoterpene mixing ratio in the standard gas was $2.35 \mathrm{ppmv}$ and the mixing ratios of methanol, acetaldehyde, acetone, and isoprene were 1 ppmv. The monoterpenes used in the calibrations were $\alpha$-pinene ( $1 \mathrm{ppmv})$, limonene $(1 \mathrm{ppmv})$, and ocimene ( $350 \mathrm{ppbv})$. The standard gas was diluted with zero air so that the mixing ratios fed into the PTR-MS were $225 \mathrm{ppbv}$ for monoterpenes and $96 \mathrm{ppbv}$ for the other compounds. The measured normalized sensitivities (Table 2) were determined for all three instruments using similar methods as described by Taipale et al. (2008). The range of normalised sensitivities measured during the second period is shown in Table 2.

VOC volume mixing ratios (VMR) were calculated using a similar approach by all groups as described by Taipale et al. (2008):

$\mathrm{VMR}=\frac{I\left(\mathrm{RH}^{+}\right)_{\text {norm }}}{S_{\text {norm }}}$ 
Table 2. Normalized sensitivities for the BVOCs presented in this paper. The PTR-MS instruments of LU and CEH were calibrated twice (on 6 and 13 May 2007) and the PTR-MS of CNR-UH was calibrated three times during the second part of the campaign (on 20, 25, and 31 May).

\begin{tabular}{lllll}
\hline $\begin{array}{l}\text { BVOC and } \\
\text { its protonated } \\
\text { mass [amu] }\end{array}$ & $\begin{array}{l}\text { Normalized } \\
\text { sensitivity } \\
\text { [ncps ppbv }^{-1} \text { ] }\end{array}$ & & & \\
\hline & & LU & CEH & CNR-UH \\
33 & methanol & 5.7 & 5.8 & $8.5-10.3$ \\
45 & acetaldehyde & 6.3 & 6.9 & $10.0-11.4$ \\
59 & acetone & 7.8 & 8.6 & $13.0-15.4$ \\
69 & isoprene & $8.3^{*}$ & $9.4^{*}$ & $6.2-7.6$ \\
81 & monoterpenes & $8.4^{*}$ & $10.0^{*}$ & $3.7-4.4$ \\
137 & monoterpenes & $5.7^{*}$ & $10.7^{*}$ & $1.1-1.5$ \\
\hline
\end{tabular}

* These values were not measured but calculated using proton transfer reaction rate coefficients and transmission coefficients. $\alpha$-pinene, limonene, and ocimene were used in the calibrations by CNR-UH.

where $S_{\text {norm }}$ is the normalized sensitivity in units of normalized counts s${ }^{-1} \mathrm{ppbv}^{-1}$ (ncps ppbv ${ }^{-1}$ ). The normalized count rate of $\mathrm{RH}^{+}$ions is

$$
\begin{aligned}
& I\left(\mathrm{RH}^{+}\right)_{\text {norm }}=I\left(\mathrm{RH}^{+}\right)\left(\frac{I\left(\mathrm{H}_{3} \mathrm{O}^{+}\right)+I\left(\mathrm{H}_{3} \mathrm{O}^{+} \mathrm{H}_{2} \mathrm{O}\right)}{I_{\text {norm }}}\right)^{-1} \\
& \left(\frac{p_{\text {drift }}}{p_{\text {norm }}}\right)^{-1}-\frac{1}{n} \sum_{i=1}^{n} I\left(\mathrm{RH}^{+}\right)_{\text {zero }, i} \\
& \left(\frac{I\left(\mathrm{H}_{3} \mathrm{O}^{+}\right)_{\text {zero }, i}+I\left(\mathrm{H}_{3} \mathrm{O}^{+} \mathrm{H}_{2} \mathrm{O}\right)_{\text {zero }, i}}{I_{\text {norm }}}\right)^{-1}\left(\frac{p_{\text {drift,zero }, i}}{p_{\text {norm }}}\right)^{-1}
\end{aligned}
$$

where $I\left(\mathrm{RH}^{+}\right), I\left(\mathrm{H}_{3} \mathrm{O}^{+}\right)$, and $I\left(\mathrm{H}_{3} \mathrm{O}^{+} \mathrm{H}_{2} \mathrm{O}\right)$ are the count rates of $\mathrm{RH}^{+}, \mathrm{H}_{3} \mathrm{O}^{+}$, and $\mathrm{H}_{3} \mathrm{O}^{+} \mathrm{H}_{2} \mathrm{O}$ ions, $p_{\text {drift }}$ is the drift tube pressure, and $n$ is the number of zero air measurement cycles. The sum of the primary and water cluster ion count rate is normalized to a count rate of $I_{\text {norm }}=10^{6} \mathrm{cps}$ and the drift tube pressure is normalized to a pressure of $p_{\text {norm }}=2 \mathrm{hPa}$. The primary ion count rate was determined using the signal of the primary ion isotopes detected at $21 \mathrm{amu}$ (M21). During the ambient concentration mode the water cluster ions were measured indirectly by recording the isotopes at M39 and multiplying by 250 to infer the total water cluster count observed at M37, thus minimising the exposure of the SEM to high count rates. In contrast, during the flux measurement mode, the water cluster ion count rate was measured directly at M37 to minimise propagation of errors when calculating fluxes. The contribution of the oxygen isotope,${ }^{16} \mathrm{O}^{17} \mathrm{O}$, was not subtracted from the signal detected at M33 when calculating the methanol mixing ratios since the oxygen count rate (M32) was not measured.

\subsection{Calculation of BVOC fluxes}

VOC fluxes were measured with the continuous flow disjunct eddy covariance method $\left(\mathrm{DEC}_{c f}\right)$. To determine the measured fluxes, $F_{m}$, a covariance function was calculated for each compound:

$F_{\mathrm{m}}(\Delta t)=\frac{1}{N} \sum_{i=1}^{N} w^{\prime}\left(i-\Delta t / \Delta t_{w}\right) c^{\prime}(i)$.

In this equation, $w^{\prime}=w-\bar{w}$ is the momentary deviation of the vertical wind speed, $w$, from its average, $c^{\prime}=c-\bar{c}$ is that of the BVOC mass concentration, $\Delta t$ is the lag time between the wind and concentration measurements, $\Delta t_{w}$ is the sampling interval in the wind measurements, and $N$ is the number of PTR-MS measurement cycles during the flux averaging time. $\mathrm{LU}$ and $\mathrm{CEH}$ used a flux averaging time of $25 \mathrm{~min}$ which corresponded to $N=1070$. The averaging time of CNR-UH was $30 \mathrm{~min}$, corresponding to $N=132$. The sampling interval was $0.05 \mathrm{~s}$ in the wind measurements of both LU-CEH and CNR-UH.

When no clear maximum was apparent in the PTR-MS signal LU used the data from the humidity sensor connected to the main sampling line at the same point as the PTR-MS to aid identification of the lag time. The humidity data were combined with the vertical wind speed data, allowing a correlation function to be applied and the lag time to be estimated. A six-second time window was used to refine the lag time. A BVOC flux measurement was rejected if no clear peak was detected above the general noise of the covariance function within the time window.

The CEH group adopted a variable lag time approach, assuming there were several sources of delays. A procedure for estimating the lag time by performing the cross-correlation between the vertical wind speed component and the BVOC signal on all individual half-hour periods for each compound separately was used. Visual assessments of both the position and the quality of the peak in the covariance function were made for all the compounds measured in the flux mode within a $10 \mathrm{~s}$ window. The rejection criteria were similar to the ones described by Spirig et al. (2005). For example the lag times for a given $\mathrm{m} / \mathrm{z}$ should not differ by more than a cycle length. Normally, variability of $2 \mathrm{~s}$ deviation from expected mean lag time was considered acceptable.

In the flux measurements by CNR-UH, the wind data were recorded on a different computer than the PTR-MS data. This means that there was an uncertainty in the timing of the wind and concentration time series in addition to the lag time due to the residence time of the sample air in the sampling lines. Therefore, the covariance functions were calculated for a rather wide lag time interval of $\pm 3 \mathrm{~min}$, using a time step of $0.05 \mathrm{~s}$. To facilitate the identification of the lag time, the covariance function was calculated also for $\mathrm{H}_{3} \mathrm{O}^{+} \mathrm{H}_{2} \mathrm{O}$ ions detected at M37 (Rinne et al., 2007). Since the signal of these water cluster ions is high and depends on the ambient 
water vapour mixing ratio (Ammann et al., 2006), there usually is a clear maximum in a covariance function related to daytime measurements. If a clear maximum could be identified from the covariance function of M37, a lag time window of $\pm 13.3 \mathrm{~s}$ around the maximum was chosen. Finally, the BVOC fluxes were determined by finding the maxima of the respective covariance functions within the lag time window. Normally, CNR-UH could calculate the fluxes from the measurements conducted between 08:00 and 21:00 LT.

Two micrometeorological quality criteria were employed in the post-processing of the flux data of LU, CEH, and CNR-UH. A flux measurement was discarded if it was obtained in stable conditions or if the friction velocity was below $0.2 \mathrm{~m} \mathrm{~s}^{-1}$. The high-frequency attenuation of the measured flux caused by the response time of the PTR-MS was estimated from the equation.

$$
\frac{F_{\mathrm{m}}}{F}=\frac{1}{1+\left(2 \pi n_{m} \tau \bar{u} /(z-d)\right)^{\alpha}}
$$

where $F$ is the non-attenuated flux, $\tau$ is the response time, and $\bar{u}$ is the average wind speed at the measurement height, $z$ (Horst, 1997). For neutral and unstable stratification, the dimensionless frequency at the cospectral maximum is $n_{m}=0.085$ and the exponent is $\alpha=7 / 8$. The displacement height was calculated using the relation $d=2 h / 3=0.80 \mathrm{~m}$ (e.g., Garratt, 1994) and the average canopy height of $h=1.2 \mathrm{~m}$. The response time was $1 \mathrm{~s}$ for the LU and CNR$\mathrm{UH}$ instruments and $0.2 \mathrm{~s}$ for the $\mathrm{CEH}$ instrument. The range of the high-frequency attenuation was $0.62-0.98$ for the LU data, 0.87-0.99 for the CEH data, and 0.45-0.97 for CNRUH data. The median values were $0.78,0.93$, and 0.71 , respectively.

\subsection{Identification of BVOCs}

To assist identification of the compounds contributing to the masses measured by PTR-MS, occasional measurements with gas-chromatographic methods were performed during the first measurement period 7-13 May. The technique has been described in more detail by Davison et al. (2008). At a flow rate of $200 \mathrm{ml} \mathrm{min}^{-1}$ a total volume of 41 air was sampled through stainless steel sampling tubes packed with Tenax and Carbopack B to pre-concentrate VOCs. These samples were analysed by thermal desorption (Perkin Elmer Turbomatrix thermal desorption system) and GC-MS (Perkin Elmer Turbomass Gold GC-MS). The compounds were separated on an Ultra 2 column $(50 \mathrm{~m} \times 0.2 \mathrm{~mm}$, I.D., $0.11 \mu \mathrm{m}$ P/N 19091-005 Agilent Technologies). Compound identification was by standards whenever possible and Wiley and NIST spectral libraries. Light compounds, usually below $\mathrm{C}_{4}$, are readily lost in the pre-concentration step on the Tenax tubes and so are not reliably detected by this method. Measurements using Tenax tubes were also made during the second measurement period and are reported in the companion paper (Fares et al., 2009).

\section{Results and discussion}

\subsection{Weather during the campaign}

Figure 1 shows meteorological parameters measured at the Castelporziano site during the campaign and longer term measurements at the CarboEurope tower about $500 \mathrm{~m}$ northeast from the site. A comparison of temperature and PAR measurements from the two sites shows a good agreement vindicating the use of measurements from the CarboEurope data set whenever meteorology data at the flux site was unavailable. During the first part of the campaign (7-14 May), the site experienced a diurnal sea breeze with winds from the sea, $180^{\circ}$ to $270^{\circ}$ during the day from around 11:00 to 19:00 LT and a land breeze from a northerly direction dominating from 03:00 or 04:00 until 11:00. The wind speed was between 0.1 and $4.3 \mathrm{~m} \mathrm{~s}^{-1}$, averaging $1.8 \mathrm{~m} \mathrm{~s}^{-1}$. The highest wind speed was observed around 13:00 with the lowest coinciding with the sea-land breeze reversal during the evening. Prior to the start of the campaign the region experienced heavy rain and flash flooding. From 1 to 7 May the site experienced $18.5 \mathrm{~mm}$ of rain of which $11.7 \mathrm{~mm}$ fell overnight on 4 May. This unsettled weather gradually gave way to clear skies and warmer conditions. The ambient temperature ranged from 13 to $24^{\circ} \mathrm{C}$ which gradually increased between 7 and 14 May. During the second part of the campaign 20 May-3 June, the sea breeze pattern was slightly more irregular. Wind direction varied typically from $180^{\circ}$ to $280^{\circ}$ between $09: 00$ and 21:00 and from $50^{\circ}$ to $150^{\circ}$ during the night. The wind speed ranged from 0.1 to $5 \mathrm{~m} \mathrm{~s}^{-1}$ with the exception of 29 May when winds up to $10 \mathrm{~m} \mathrm{~s}^{-1}$ were observed. The highest values were observed between 14:00 and 19:00 and the lowest between 21:00 and 02:00. The air temperature ranged from 10 to $31^{\circ} \mathrm{C}$ and the typical values were $19-23^{\circ} \mathrm{C}$ in the daytime and $15-19^{\circ} \mathrm{C}$ at night. The daily maximum values of photosynthetically active radiation were around $1400-1900 \mu \mathrm{mol} \mathrm{m}^{-2} \mathrm{~s}^{-1}$. The cumulative rainfall during 20 May-3 June was $22 \mathrm{~mm}$. The most intensive showers took place on 28 and 29 May and there was a period of continuous rain on 3 June.

\subsection{BVOC mixing ratios}

Figure 2 shows the half-hour averages of the mixing ratios of methanol, acetaldehyde, acetone, isoprene, and monoterpenes during the measurement campaign. In general, the agreement between the simultaneous measurements with the LU and CEH instruments was good, particularly for methanol with a correlation coefficient $\left(R^{2}\right)$ of over 0.98 . The correlation coefficients for the other compounds ranged from 0.89 for acetaldehyde to 0.94 for monoterpenes. The $\mathrm{LU}$ and $\mathrm{CEH}$ isoprene and monoterpene concentrations were calculated using PTR-MS transmission factors as gas standards were not available for these compounds. The results from the two periods in early and late May exhibit similar 
Table 3. Medians of BVOC mixing ratios and fluxes calculated from all, daytime (12:00-17:00), and night-time (00:00-05:00) measurements. The measurement period was 7-14 May 2007 for LU and CEH and 20 May-3 June 2007 for CNR-UH. The number of measurements contributing to the median is given in parentheses.

\begin{tabular}{|c|c|c|c|c|c|c|c|c|c|}
\hline & \multicolumn{3}{|c|}{$\mathrm{LU}$} & \multicolumn{3}{|c|}{$\mathrm{CEH}$} & \multicolumn{3}{|c|}{ CNR-UH } \\
\hline & \multicolumn{9}{|c|}{ Volume mixing ratio [ppbv] } \\
\hline & $\begin{array}{l}\text { all } \\
(339- \\
340)\end{array}$ & $\begin{array}{l}\text { day } \\
(63-64)\end{array}$ & $\begin{array}{l}\text { night } \\
\text { (76) }\end{array}$ & $\begin{array}{l}\text { all } \\
(245)\end{array}$ & $\begin{array}{l}\text { day } \\
(57)\end{array}$ & $\begin{array}{l}\text { night } \\
\text { (46) }\end{array}$ & $\begin{array}{l}\text { all } \\
(441-480)\end{array}$ & $\begin{array}{l}\text { day } \\
(91- \\
102)\end{array}$ & $\begin{array}{l}\text { night } \\
(98- \\
107)\end{array}$ \\
\hline methanol & 3.51 & 4.07 & 2.73 & 3.44 & 4.32 & 2.56 & 1.64 & 1.72 & 1.58 \\
\hline acetaldehyde & 0.980 & 1.32 & 0.674 & 1.29 & 1.74 & 0.641 & 0.441 & 0.519 & 0.404 \\
\hline acetone & 1.58 & 2.36 & 0.962 & 2.07 & 2.84 & 1.24 & 0.964 & 1.15 & 0.889 \\
\hline isoprene & 0.103 & 0.160 & 0.0760 & 0.135 & 0.253 & 0.062 & 0.130 & 0.166 & 0.108 \\
\hline \multirow[t]{3}{*}{ monoterpenes } & 0.303 & 0.208 & 0.577 & 0.132 & 0.102 & 0.264 & 0.181 & 0.161 & 0.357 \\
\hline & \multicolumn{9}{|c|}{ Flux $\left[\mu \mathrm{g} \mathrm{m}^{-2} \mathrm{~h}^{-1}\right]$} \\
\hline & $\begin{array}{l}\text { all } \\
(54-69)\end{array}$ & $\begin{array}{l}\text { day } \\
(22-27)\end{array}$ & $\begin{array}{l}\text { night } \\
(1-3)\end{array}$ & $\begin{array}{l}\text { all } \\
(81-97)\end{array}$ & $\begin{array}{l}\text { day } \\
(32-41)\end{array}$ & $\begin{array}{l}\text { night } \\
(2-3)\end{array}$ & $\begin{array}{l}\text { all } \\
(106-112)\end{array}$ & $\begin{array}{l}\text { day } \\
(62-66)\end{array}$ & $\begin{array}{l}\text { night } \\
(0)\end{array}$ \\
\hline methanol & 421 & 579 & -125 & 439 & 597 & -205 & 368 & 424 & \\
\hline acetaldehyde & 301 & 391 & -132 & 363 & 422 & -188 & 180 & 185 & \\
\hline acetone & 299 & 411 & 11.7 & 448 & 543 & -146 & 182 & 212 & \\
\hline isoprene & 70.5 & 96.6 & -36.0 & 125 & 160 & -47.5 & 290 & 317 & \\
\hline monoterpenes & 240 & 325 & 183 & 254 & 320 & -102 & 857 & 963 & \\
\hline
\end{tabular}

overall trends though the average mixing ratios of methanol, acetaldehyde, and acetone were slightly lower during the second period.

Table 3 shows a summary of the concentration results from the two measurement periods. During the first measurement period (7-14 May 2007) concentrations of all species were highest during the first few days. Methanol emissions are known to be influenced by abiotic stress factors such as elevated ozone levels, drought, flooding and mechanical leaf wounding (Fukui and Doskey, 1998; Holzinger et al., 2000; Beauchamp et al., 2005; Karl et al., 2005; Loreto et al. 2006; Brunner et al., 2007; Penuelas et al., 2005) as well as leaf age, with higher emissions typical of young developing leaves (Nemecek-Marshall et al., 1995). BVOC emissions, in particular of methanol are strongly dependent on water soil content and photosynthesis. Whether the elevated concentration levels observed over the first few days of the campaign were due to the heavy rain encountered during this period or disturbance of the site during setting up is unclear but there were also notably higher concentrations during the early part of the second period of the campaign (20 May to 3 June 2007).

An analysis of various meteorological factors such as temperature, RH and light did not show any clear correlation across the data set. While there was some agreement between temperature and oxygenated VOC concentrations for part of the data during the beginning of the second sampling period this was not consistent across the whole data set. The leaf level measurements performed throughout the campaign indicated the plants were not showing any signs of stress due to the heavy rainfall during the first period or the higher temper- atures of the second period. Damaged plant can emit considerable amounts of VOC. As no other reason for the elevated concentrations can be definitely identified mechanical plant damage during set up must also be considered as a possible source of the elevated VOC concentrations observed at the beginning of both sampling periods.

Measurements over crop fields have shown methanol to be one of the most abundant biogenically emitted VOCs (Warneke et al., 2002; Fall, 2003; Schade and Custer, 2004; Davison et al., 2008). Our data confirms that methanol is also a prominent BVOC in natural ecosystems. Along with acetaldehyde, acetone and isoprene, methanol showed a similar trend with a clear diurnal cycle with a daytime maximum. Monoterpenes showed a diurnal trend but with a night time maximum. Measurements during the original BEMA campaigns observed oxygenated compounds emitted from pine and oak species. Acetic and formic acid, and acetaldehyde and formaldehyde were collected by a cartridge trap technique which was less sensitive, less compound-specific and with poorer resolution, than the PTR-MS available during this campaign (Kesselmeier et al., 1997). The results did however show broadly similar diurnal trends to those observed during this campaign with ambient concentrations varying from 0 to $7 \mathrm{ppbv}$ with a daytime maximum. This has proved to be in keeping with the measurements from this campaign where a 4 ppbv daytime maximum concentrations was measured using PTR-MS.

On a daily basis, concentrations of methanol, acetaldehyde, acetone and isoprene typically began to increase at around 07:00 local time (05:00 UTC). Methanol and 

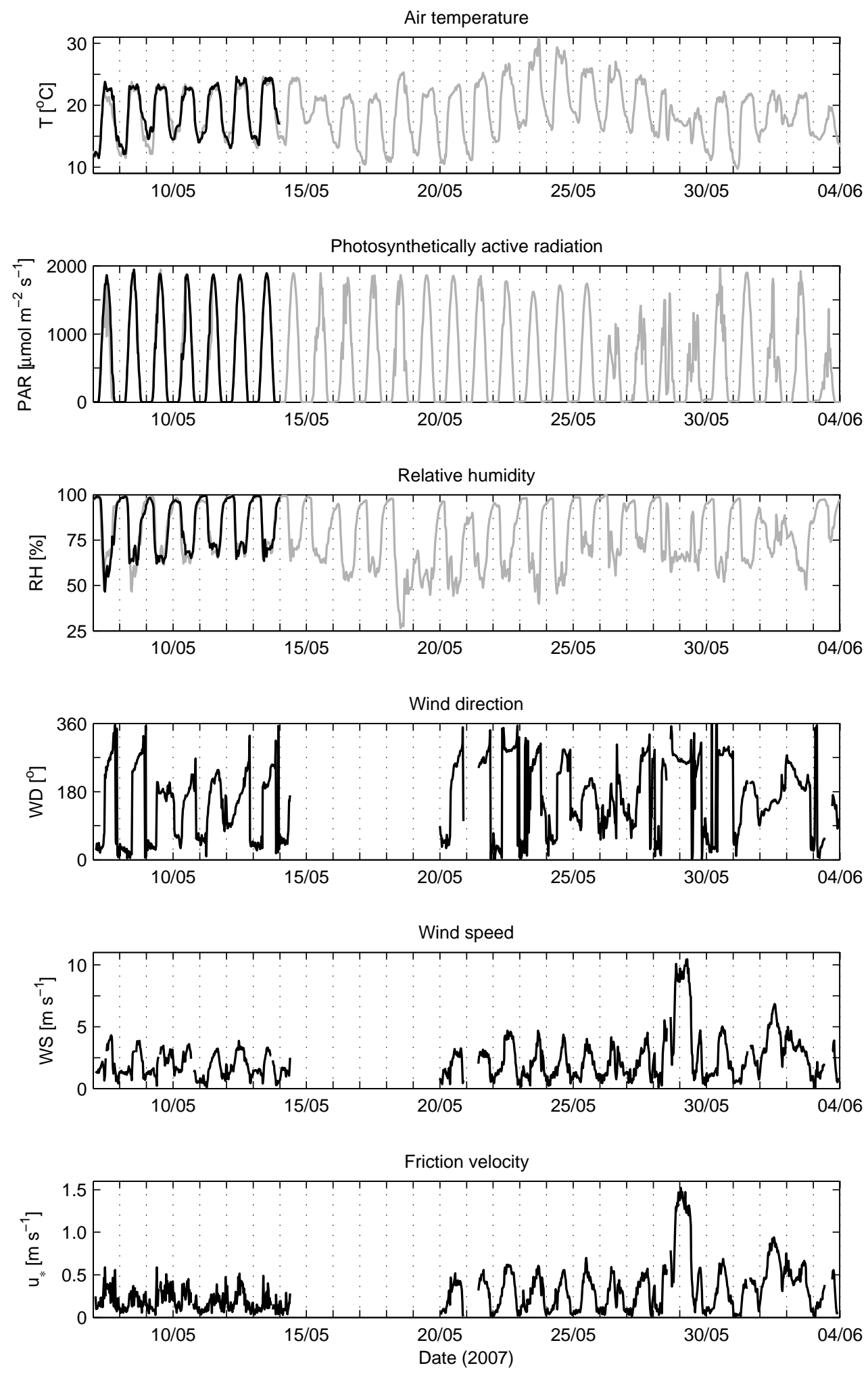

Fig. 1. Meteorological variables measured at the Castelporziano site (black lines) and the CarboEurope tower (grey lines). 

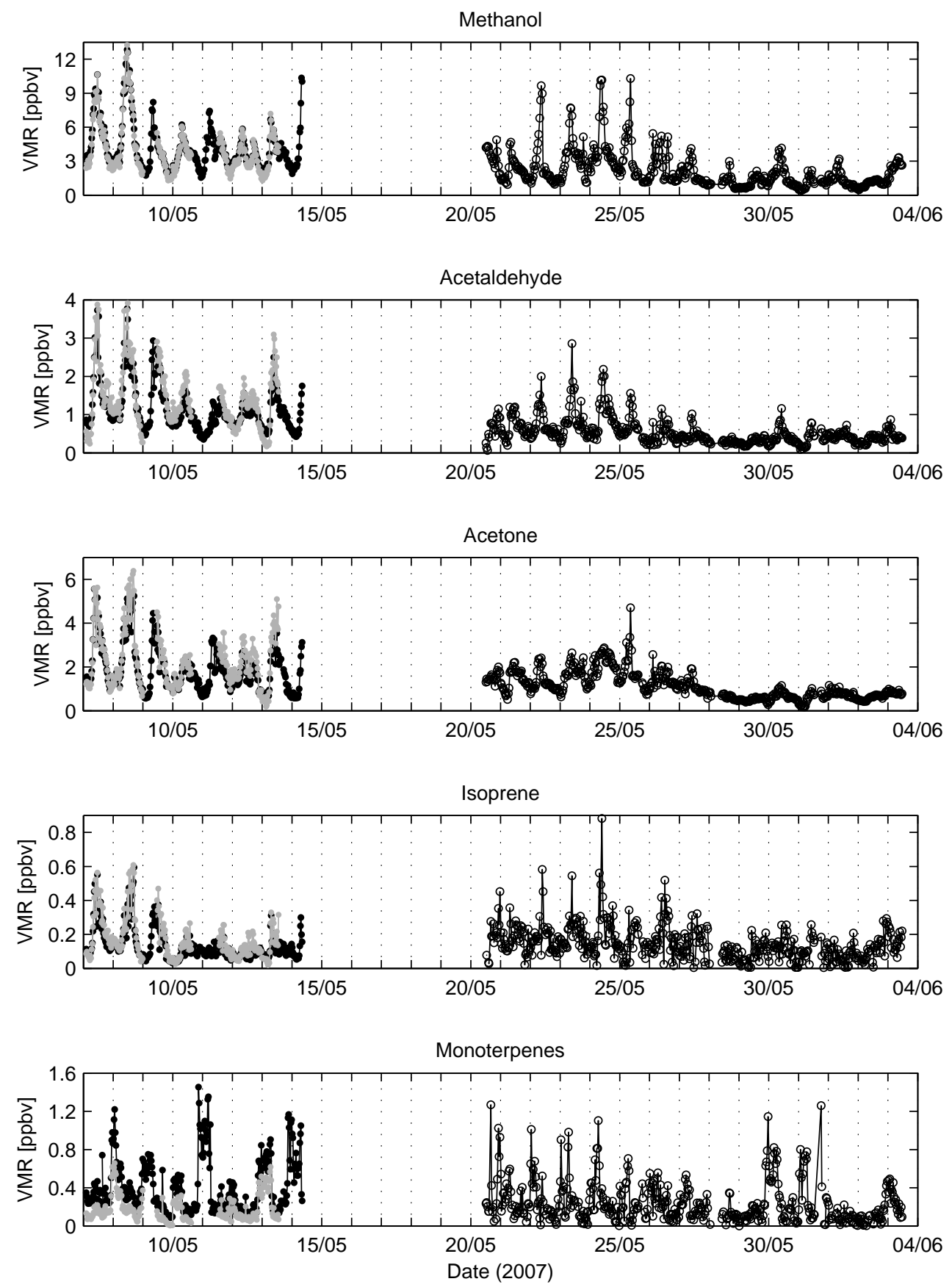

Fig. 2. Half-hour averages of BVOC mixing ratios measured by LU (black circles, 7-14 May), CEH (grey circles), and CNR-UH (open circles, 20 May-3 June).

acetaldehyde both peaked in the early morning (10:00) with a secondary afternoon peak followed by a gradual decrease throughout the rest of the day. Plant physiology controls the emissions of methanol from vegetation through relationships to plant growth (Fall and Benson, 1996; Schade and Goldstein, 2006; Folkers et al., 2008), cell expansion and protein repair reactions (Mudgett and Clarke, 1993). The emis- sion of methanol is controlled via the transpiration stream, which is itself governed by light and leaf temperature (which explains the close agreement with temperature), as well as stomatal conductance (Niinemets et al., 2004). Methanol is associated with cell wall degradation during leaf expansion, which happen especially during night time. Huve et al. (2007) described a strong dependence of methanol on 
stomatal conductance because methanol can accumulate in the intercellular spaces and be released when stomata open. This is consistent with the observed measurements of concentration in the early morning, coincident with stomatal opening.

Similar trends were observed by Kesselmeier et al. (1997) for acetic and formic acid released from oak and related to transpiration patterns. The strong stomatal dependency of the emission of soluble compounds, such as methanol has been highlighted previously (Niinemets et al., 2004; Huve et al., 2007).

Measurements of acetone, although similar to those of methanol and acetaldehyde, showed some differences, such as a sharp decline in concentration at around 19:00. Isoprene concentrations increased throughout the afternoon after an initial peak at 08:00, to reach a maximum at 14:00, before decreasing sharply, similar to acetone. Ozone measurements at the site showed a diurnal trend with a daytime maximum occurring a few hours after the maximum in BVOC concentrations. This maximum probably relates more to the change in direction of the sea-land breeze than to any reaction with VOCs emitted from the vegetation.

The low molecular weight compounds (methanol, acetaldehyde, acetone and isoprene), as well as showing similar trends, had good correlation between each compound when all measurements are plotted together. The correlation coefficients ranged from an $R^{2}=0.52$ between methanol and isoprene to a $R^{2}=0.78$ for acetone and acetaldehyde. While VOC concentrations show general agreement with meteorological parameters, such as light and temperature, the correlation was generally not as pronounced as for isoprene or monoterpene and no clear drivers could be identified from the field data to explain the variations observed. These compounds are known to have different biosynthetic pathways and any close correlation may suggest similar meteorological controls (e.g. light and temperature) on the precursors or on the enzymes that catalyze the limiting biosynthetic steps. For example, the metabolic production of isoprenoid precursor (predominantly photosynthetates) and the demethylation of pectins in the cell walls for methanol production may be similarly controlled by the environmental factors. It is also possible that the control of all emitted compounds also includes a physico-chemical component, mainly attributable to stomatal conductance, although Niinemets et al. (2004) mainly assign such a physical control to oxygenated hydrocarbons only.

A wind rose of BVOC concentrations and fluxes (Fig. 3) shows a scatter of concentrations around the site with predominance of daytime concentrations coming from the seaward side and night time concentrations from the landward side of the sampling footprint due to the sea-land breeze effect. Unlike the other BVOCs measured, the highest monoterpene concentrations originate from the north-east. This trend was more pronounced during the first part of the campaign, which experienced a more noticeable breeze ef-
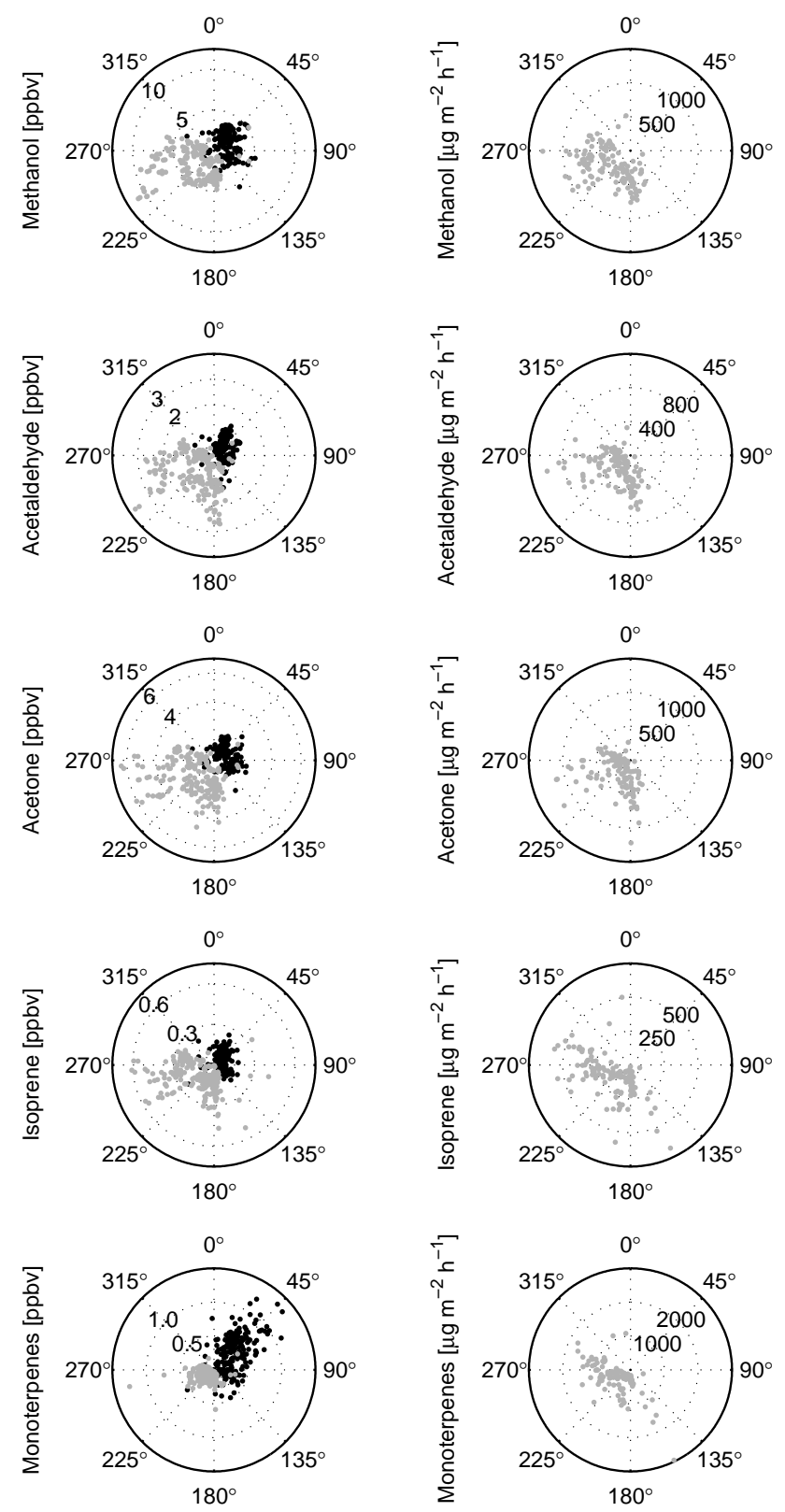

Fig. 3. Wind roses of BVOC mixing ratios and fluxes measured by LU, CEH, and CNR-UH. The grey circles represent the measurements made between 12:00 and 17:00 (day) and the black circles show the measurements between 00:00 and 05:00 (night).

fect than during the second measurement period. A natural forest of Holm oak, a known monoterpene emitter, and a plantation of stone pine are located in this direction.

The highest monoterpene concentrations during both campaign periods were observed at night once the wind had switched direction and the land breeze dominated, bringing air from the Holm oak and stone pine forest to the measurement site. While monoterpene emissions from Holm oaks is mainly controlled by light they continue to emit 
monoterpenes at night although at much lower rates than during the day (Street et al., 1997; Staudt and Bertin, 1998; Grote et al., 2006). A considerable fraction of the monoterpene emission from pines originates from large storage structures and as such they continue to emit at night at a higher relative level than Holm oaks provided nocturnal temperatures remain sufficiently high (Owen et al., 1997; Staudt et al., 1997). While the emissions from this species are lower at night the rapid removal of compounds by reaction with light induced hydroxyl radicals ceases and the vertical mixing is strongly suppressed, leading to high surface layer concentrations. This, in conjunction with the wind direction change, leads to higher night time monoterpene concentrations being observed. A similar directional trend is not apparent in the monoterpene flux (Fig. 3), though most night time fluxes failed the flux acceptance criteria due to the stable boundary layer conditions.

Monoterpene emissions were higher during the second period of the campaign, both as measured by PTR-MS over the sampling site and from leaf cuvette measurements of specific plant species. This may be related to the temperature, which was approximately $3^{\circ} \mathrm{C}$ higher during the second part of the campaign (Fares et al., 2009), and the more advanced phenological state of the plants in the flux footprint area. Isoprene emission is known to be dependent on leaf development (Wiberley et al., 2005) and monoterpene emission from deciduous broad leafed trees exhibit the same developmental behaviour (Hakola et al., 1998; Kuhn et al., 2004).

The concentrations measured simultaneously by the CEH and LU PTR-MS instruments were almost identical in patterns. The absolute values for the compounds for which external calibration was available was very good, but worse for monoterpenes and isoprene, whose sensitivities were calculated during the first part of the campaign using the instrumental transmission rather than calibration with gas standards. This indicates that external standards are required for the highest accuracy of results, as the differences between calculated and measured sensitivities have been reported to be up to a factor of 2 (Warneke et al., 2002; de Gouw and Warneke, 2007).

\subsection{BVOC fluxes}

Figure 4 shows the fluxes of the five BVOCs emitted by the macchia as measured during the first and second period of the campaign. Emission rates were highest during mid to late afternoon and lowest during the night. This reflects the diurnal cycle of the biological and physical processes affecting the emissions. Most of the night time flux data were rejected due to quality criteria, as the stably stratified conditions, low wind speeds and weak mixing often encountered at night time leads to a decoupling of measured fluxes from surface exchange, so cases of low friction velocity (below $0.2 \mathrm{~m} \mathrm{~s}^{-1}$ ) are routinely excluded from flux calculations (Goulden et al., 1996; Göckede et al., 2004).
Methanol fluxes closely followed the diurnal profile of light and temperature with emissions peaking at around midday. The concentration measurements showed a slight difference peaking in early morning, before declining steadily throughout the afternoon.

The fluxes derived by the two groups in the first period agree reasonably well, showing the scale of uncertainty caused by individual lag time determination, which was done separately by each group, leading to a slight difference in the amount of data rejected due to an unclear lag time. The negative fluxes may be the result of flux divergence, with considerable uncertainties from advection and general low turbulence conditions. The fluxes of monoterpenes were derived differently by both groups in the first period. For example, in the processing of CEH data, the lag times for $\mathrm{m} / \mathrm{z} 81$ and $\mathrm{m} / \mathrm{z} 137$ were derived independently, while in the LU analysis the lag times were derived for the sum of the fragments. This led to coincidental good agreement in values, but in fact the LU flux should be higher, considering the higher concentrations that were reported.

The canopy flux measurements were used to calculate an ecosystem scale basal emission rate for the footprint area of the Macchia vegetation by fitting the flux data to the light and temperature dependent G97 algorithm of Guenther (1997). As the basal emission rates are expected to change with leaf development, we divided the measured time series into three sections: 7 to 14 May, 20 to 27 May, and 28 May to 3 June. The measured fluxes were fitted to the emission activity factors separately for these periods.

For the first period of the campaign the isoprene basal emission rate calculated from the flux measurements was $315 \mu \mathrm{g} \mathrm{m}^{-2} \mathrm{~h}^{-1}$ with a monoterpene emission rate of $710 \mu \mathrm{g} \mathrm{m}^{-2} \mathrm{~h}^{-1}$. During the second sampling period meterological conditions changed just prior to a small storm on 28 May and activity factors were noted to have been affected. This point has therefore been used as a cut off when calculating basal emission rates. Basal emission rates calculated between 20 to 27 May showed isoprene rates of $511 \mu \mathrm{g} \mathrm{m}^{-2} \mathrm{~h}^{-1}$ a and monoterpene rates of $1490 \mu \mathrm{g} \mathrm{m}^{-2} \mathrm{~h}^{-1}$ while the period after the storm, from 28 May to 3 June had emission rates of $1010 \mu \mathrm{g} \mathrm{m}^{-2} \mathrm{~h}^{-1}$ for isoprene and $3290 \mu \mathrm{g} \mathrm{m}^{-2} \mathrm{~h}^{-1}$ for monoterpenes. This increase in the basal emission rate throughout the measurements period may reflect the physiological state of the plants as they developed over the months (Kuhn et al., 2004).

Fares et al. (2009) from leaf and plant emission measurements made during the second part of this study calculated an isoprene emissioin rate of $79 \mu \mathrm{g} \mathrm{m}^{-2} \mathrm{~h}^{-1}$ and a monoterpene emission rate of $1199 \mu \mathrm{g} \mathrm{m}^{-2} \mathrm{~h}^{-1}$ while Owen et al. (1997) calculated a rate of $563 \mu \mathrm{g} \mathrm{m}^{-2} \mathrm{~h}^{-1}$ for isoprene and $918 \mu \mathrm{g} \mathrm{m}^{-2} \mathrm{~h}^{-1}$ for monoterpene from the Macchia area during May.

The basal emission rates show a reasonable agreement, only the isoprene value of Fares et al. (2009) at $79 \mu \mathrm{g} \mathrm{m}^{-2} \mathrm{~h}^{-1}$ is significantly below other estimates. Using 

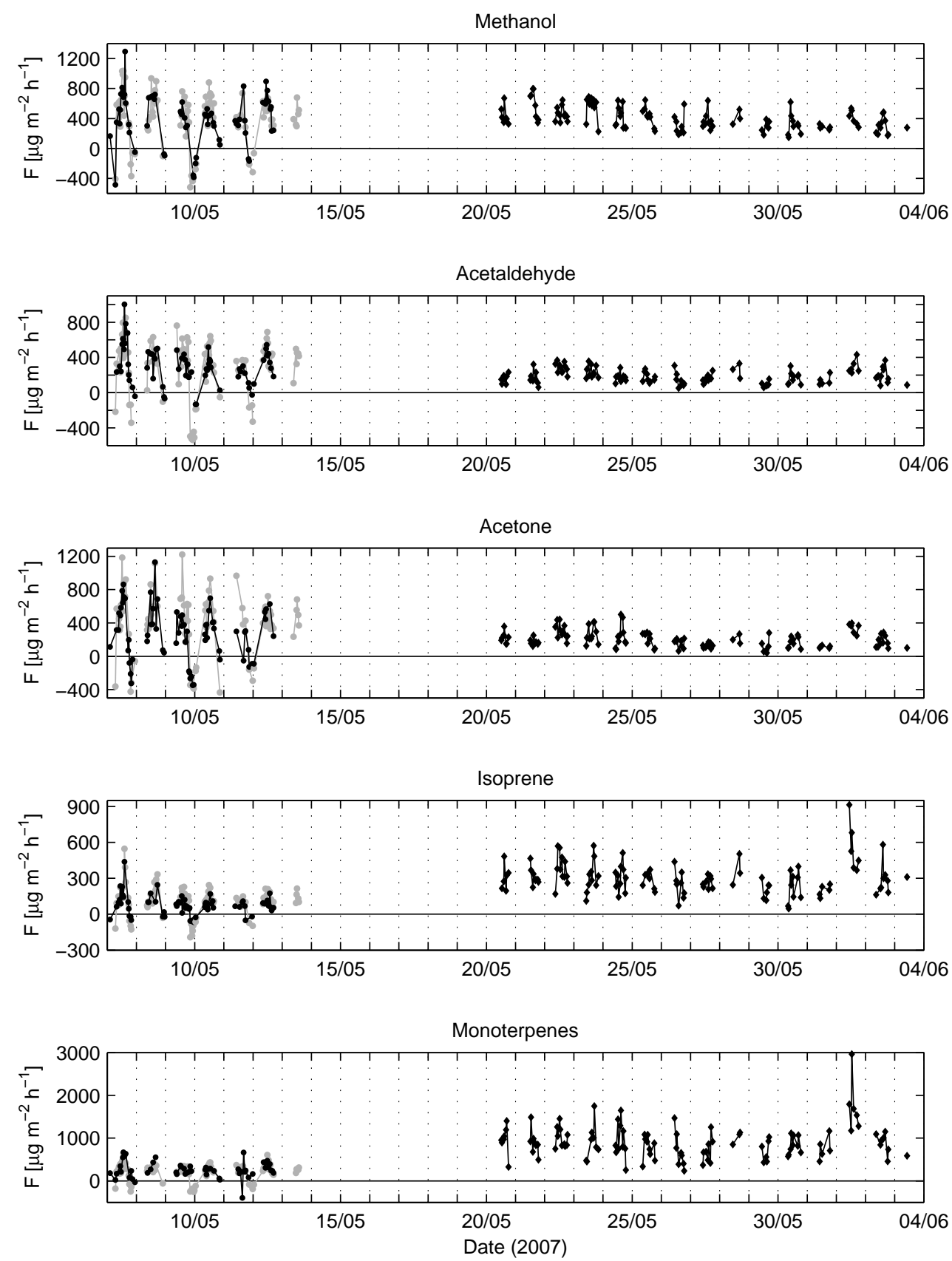

Fig. 4. BVOC fluxes measured by LU (black circles, 7-12 May), CEH (grey circles), and CNR-UH (black diamonds, 20 May-3 June).

a bottom up approach for calculating an area basal emission rate is highly dependent upon the plant species selected and the estimation of coverage over the area which may explain the large difference between the isoprene emission potential of Fares et al. (2009) and that calculated from our flux rate approach.

Isoprene and monoterpene fluxes were calculated using the algorithm from Guenther (1997; G97) which assumes light and temperature dependent isoprene and monoterpene emitters. These model results were compared with the measured fluxes obtained using the $\mathrm{DEC}_{c f}$ technique. As can be seen from Fig. 5 the G97 isoprene emission algorithm describes the ecosystem scale emissions of both isoprene and monoterpenes reasonably well when fitted to the available measured data. We can see the general increase of emission potentials during the campaign. This is likely due to the effect of the leaf phenology in the emission of terpenoids, as at the same time the methanol emission is decreasing, but the 

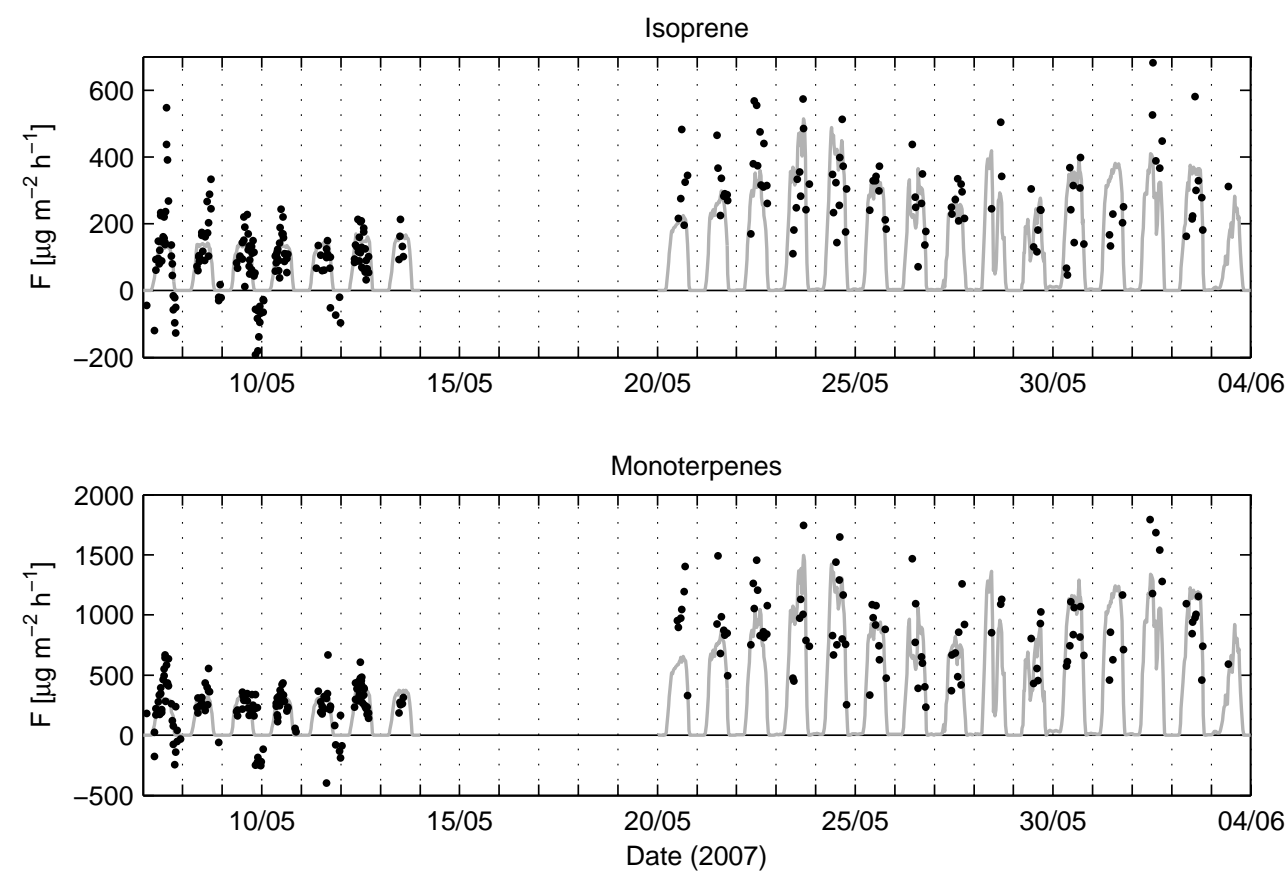

Fig. 5. Comparison of the measured (black circles) and modelled isoprene and monoterpene emissions from the G97 algorithm.

direct effect of rising temperatures during the season cannot be ruled out altogether. Leaf development changes leaf scale emissions, the amount of emitting biomass, and microclimate of the canopy. Since the emission factors used in this work depend only on light and temperature, the ecosystem scale basal rates can include effects of other variables as well.

\section{Conclusions}

High resolution atmospheric measurements of the oxygenated biogenic VOCs, methanol, acetaldehyde and acetone, along with isoprene and monoterpenes, were conducted at a site among macchia vegetation at Castelporziano, Italy during two periods 7 to 14 May and 20 May to 3 June 2007. These data allowed for the first set of direct, canopy-scale VOC flux measurements above Mediterranean Macchia vegetation which considerably enhances the leaf-level emission estimates made during the original BEMA campaign.

Monoterpene basal emission rates calculated using our direct flux measurements for the Macchia site show reasonable agreement with emission rates calculated from leaf measurements. Yet, there is considerable difference between the basal emission rates for isoprene which may be due to unrepresentative sampling of species in the measurement area.

The VOC concentrations showed a clear diurnal cycle with a daytime maximum for methanol, acetaldehyde, acetone and isoprene and a night time maximum in monoterpene concentrations. In contrast a daytime maximum was observed in monoterpene fluxes. During the campaign the monoterpenes measured at night time were advected horizontally into the flux footprint area from a nearby Holm oak and pine forest once the wind direction had switched to a land breeze. This explains the night time maximum in concentrations and daytime maximum in monoterpene fluxes from the vegetation within the flux footprint area.

The campaign offered the opportunity to compare results from three PTR-MS instruments with slightly differing sampling protocols. The results obtained show good instrumental agreement, and confirm the reliability of this instrument for field research.

Acknowledgements. We thank the European Network of Excellence of Atmospheric Composition Change (ACCENT) and the Volatile Organic Compounds in the Biosphere-Atmosphere System (VOCBAS) project of the European Science Foundation for financial support. We acknowledge Riccardo Valentini for use of meteorology data and Annette Ryan and Malcolm Possell for plant phenology information and advice. We thank the Academy of Finland, (projects 120434, 125 238, and 209216), Helsinki University Centre for Environment and the Kone Foundation for additional financial support. We would also like to express our gratitude to the Scientific Committee of the Presidential Estate of Castelporziano and in particular to Giantommaso Scarascia Mugnozza and to Aleandro Tinelli.

Edited by: A. Arneth 


\section{References}

Ammann, C., Brunner, A., Spirig, C., and Neftel, A.: Technical note: Water vapour concentration and flux measurements with PTR-MS, Atmos. Chem. Phys., 6, 4643-4651, 2006,

http://www.atmos-chem-phys.net/6/4643/2006/.

Beauchamp, J., Wisthaler, A., Hansel, A., Kleist, E., Miebach, M., Niinemets, U., Schurr, U., and Wildt, J.: Ozone induced emissions of biogenic VOC from tobacco: Relationships between ozone uptake and emission of LOX products, Plant Cell Environ., 28, 1334-1343, 2005.

Bertin, N., Staudt, M., Hansen, U., Seufert, G., Ciccioli, P., Foster, P., Fugit, J. L., and Torres, L.: Diurnal and seasonal course of monoterpene emissions from Quercus ilex (L.) under natural conditions - application of light and temperature algorithms, Atmos. Environ., 31(SI), 135-144, 1997.

Brunner, A., Ammann, C., Neftel, A., and Spirig, C.: Methanol exchange between grassland and the atmosphere. Biogeosciences, 4, 395-410, 2007

Ciccioli, P., Fabozzi, C., Brancaleoni, E., Cecinato, A., Frattoni, M., Cieslik, S., Kotzias, D., Seufert, G., Foster, P., and Steinbrecher, R.: Biogenic emission from the Mediterranean pseudosteppe ecosystem present in Castelporziano, Atmos. Environ., 31(SI), 167-175, 1997.

Davison, B., Brunner, A., Ammann, C., Spirig, C., Jocher, M., and Neftel, A.: Cut induced VOC emissions from agricultural grasslands. Plant Biol., 10, 76-85, doi:10.1055/s-2007-965043, 2008.

de Gouw, J. and Warneke, C.: Measurements of volatile organic compounds in the Earth's atmosphere using proton-transferreaction mass spectrometry, Mass Spectrom. Rev., 26, 223-257, 2007.

Fall, R. and Benson, A. A.: Leaf methanol - the simplest natural product from plants, Trends Plant Sci., 1, 296-301, 1996.

Fall, R.: Abundant oxygenates in the atmosphere: A biochemical perspective, Chem. Rev., 103, 4941-4951, 2003.

Fares, S., Mereu, S., Scarascia-Mugnozza, G., Vitale, M., Frattoni, M., Ciccioli, P., and Loreto, F.: The ACCENT-VOCBAS field campaign on biosphere-atmosphere interactions in a Mediterranean ecosystem of Castelporziano (Rome): site characteristics, climatic and meteorological conditions, and eco-physiology of vegetation, Biogeosciences, 6, 1043-1058, 2009 2009.

Folkers, A., Huve, K., Ammann, C., Dindorf, T., Kesselmeier, J., Kleist, E., Kuhn, U., Uerlings, R., and Wildt, J.: Methanol emissions from deciduous tree species: Dependence on temperature and light intensity, Plant Biol., 10, 65-75, 2008.

Fowler, D.: Ground-level ozone in the 21 st century: future trends, impacts and policy implications, Royal Society, London, UK, 2008.

Fukui, Y. and Doskey, P. V.: Air-surface exchange of non-methane organic compounds at a grassland site: Seasonal variations and stressed emissions, J. Geophys. Res.-Atmos., 103, 13153-13168, 1998.

Garratt, J. R.: The atmospheric boundary layer, Cambridge University Press, Cambridge, UK, pp. 316, 1994.

Göckede, M., Rebmann, C., and Foken, T.: A combination of quality assessment tools for eddy covariance measurements with footprint modelling for the characterisation of complex sites, Agr. For. Meteorol., 127, 175-188, 2004.

Goulden, M. L., Munger, J. W., Fan, S.-M., Daube, B. C., and
Wofsy, S. C.: Measurements of carbon sequestration by longterm eddy covariance: methods and a critical evaluation of accuracy, Global Change Biol., 2, 169-182, 1996.

Grote, R., Mayrhofer, S., Fischbach, R. J., Steinbrecher, R., Staudt, M., and Schnitzler, J. P.: Process-based modelling of isoprenoid emissions from evergreen leaves of quercus ilex (1.), Atmos. Environ., 40, S152-S165, 2006.

Guenther, A. B., Zimmerman, P. R., Harley, P. C., Monson, R. K., and Fall, R.: Isoprene and monoterpene emission rate variability: model evaluations and sensitivity analyses, J. Geophys. Res., 98(D7), 12609-12617, 1993.

Guenther, A., Hewitt, C. N., Erickson, D., Fall, R., Geron, C., Graedel, T., Harley, P., Klinger, L., Lerdau, M., McKay, W. A., Pierce, T., Scholes, B., Steinbrecher, R., Tallamraju, R., Taylor, J., and Zimmerman, P.: A global model of natural volatile organic compound emissions, J. Geophys. Res., 100(D5), 88738892, 1995.

Guenther, A.: Seasonal and spatial variations in natural volatile organic compound emissions. Ecol. Appl., 7, 34-45, 1997.

Hakola, H., Rinne, J., and Laurila, T.: Hydrocarbon emission rates of tea-leafed willow (Salix phylicifolia), Silver birch (Betula pendula) and European aspen (Populus tremula), Atmos. Environ., 32, 1825-1833, 1998.

Hansel, A., Jordan, A., Holzinger, R., Prazeller, P., Vogel, W., and Lindinger, W.: Proton transfer reaction mass spectrometry: online trace gas analysis at the ppb level, Int. J. Mass Spectrom., 149-150, 609-619, 1995.

Hayward, S., Tani, A., Owen, S. M., and Hewitt, C. N.: Online analysis of volatile organic compound emissions from Sitka spuce (Picea sitchensis). Tree Physiology, 24, 721-728, 2004.

Helmig, D., Klinger, L.F., Guenther, A., Vierling, L., Geron, C., and Zimmerman, P.: Biogenic volatile organic compound emission (BVOCs): II. Landscape flux potentials from three continental sites in the US, Chemosphere, 38(9), 2189-2204, 1999.

Hewitt, C. N., Hayward, S., and Tani, A. Application of proton transfer reaction mass spectrometry for the monitoring and measurement of volatile organic compounds in the atmosphere, Environ. Monitor., 5, 1-7, 2003.

Holzinger, R., Sandoval-Soto, L., Rottenberger, S., Crutzen, P. J., and Kesselmeier, J.: Emissions of volatile organic compounds from quercus ilex 1 . Measured by proton transfer reaction mass spectrometry under different environmental conditions, J. Geophys. Res.-Atmos., 105, 20573-20579, 2000.

Horst, T. W.: A simple formula for attenuation of eddy fluxes measured with first-order-response scalar sensors, Bound.-Layer Meteorol., 82, 219-233, 1997.

Huve, K., Christ, M. M., Kleist, E., Uerlings, R., Niinemets, U., Walter, A., and Wildt, J.: Simultaneous growth and emission measurements demonstrate an interactive control of methanol release by leaf expansion and stomata, J. Exp. Bot., 58(7), 17831793, 2007.

Karl, T. G., Spirig, C., Rinne, J., Stroud, C., Prevost, P., Greenberg, J., Fall, R., and Guenther, A.: Virtual disjunct eddy covariance measurements of organic compound fluxes from a subalpine forest using proton transfer reaction mass spectrometry, Atmos. Chem. Phys., 2, 279-291, 2002,

http://www.atmos-chem-phys.net/2/279/2002/.

Karl, T., Harley, P., Guenther, A., Rasmussen, R., Baker, B., Jardine, K., and Nemitz, E.: The bi-directional exchange of oxy- 
genated vocs between a Loblolly pine (Pinus Taeda) plantation and the atmosphere, Atmospheric Chemistry And Physics, 5, 3015-3031, 2005.

Kesselmeier, J., Bode, K., Hofmann, U., Müller, H., Schäfer, L., Wolf, A., Ciccioli, P., Brancaleoni, E., Cecinato, A., Frattoni, M., Foster, P., Ferrari, C., Jacob, V., Fugit, J. L., Dutaur, L., Simon, V., and Torres, L.: Emission of short chained organic acids, aldehydes and monoterpenes from Quercus ilex L. and Pinus pinea L. in relation to physiological activities, carbon budget and emission algorithms, Atmos. Environ., 31(SI), 119-133, 1997.

Kuhn, U., Rottenberger, S., Biesenthal, T., Wolf, A., Schebeske, G., Ciccioli, P., and Kesselmeier, J.,: Strong correlation between isoprene emission and gross photosynthetic capacity during leaf phenology of the tropical tree species Hymenaea courbaril with fundamental changes in volatile organic compounds emission composition during early leaf development, Plant Cell Environ., 27(12), 1469-1485, 2004.

Lindinger, W., Hansel, A., and Jordan, A.: On-line monitoring of volatile organic compounds at pptv levels by means of ProtonTransfer-Reaction Mass Spectrometry (PTR-MS) - Medical applications, food control and environmental research, Int. J. Mass Spectrom., 173, 191-241, 1998.

Loreto, F., Barta, C., Brilli, F., and Nogues, I.: On the induction of volatile organic compound emissions by plants as consequence of wounding or fluctuations of light and temperature, Plant Cell Environ., 29, 1820-1828, 2006.

Mudgett, M. B., and Clarke, S.: Characterization of plant 1isoaspartyl methyltransferases that may be involved in seed survival - purification, cloning, and sequence-analysis of the wheatgerm enzyme, Biochemistry, 32, 11100-11111, 1993.

Nemecek-Marshall, M., MacDonald, R. C., Franzen, J. J., Wojciechowski, C. L. and Fall, R.: Methanol Emission from Leaves (Enzymatic Detection of Gas-Phase Methanol and Relation of Methanol Fluxes to Stomatal Conductance and Leaf Development), Plant Physiol., 108, 4, 1359-1368. 1995

Niinemets, U., Loreto, F., and Reichstein, M.: Physiological and physicochemical controls on foliar volatile organic compund emissions. Trends in plant science, 4, 180-186, 2004.

Owen, S. M., Boissard, C., Street, R. A., Duckham, S. C., Csiky, O., and Hewitt, C. N.: Screening of 18 Mediterranean plant species for volatile organic compound emissions, Atmos. Environ., 31(SI), 101-117, 1997.

Owen, S. M., Boissard, C., and Hewitt, C. N.: Volatile organic compounds (vocs) emitted from 40 mediterranean plant species: Voc speciation and extrapolation to habitat scale, Atmos. Environ., 35, 5393-5409, 2001.

Owen, S. M., Harley, P., Guenther, A., and Hewitt, C. N.: Light dependency of VOC emissions from selected Mediterranean plant species, Atmos. Environ., 36, 3147-3159, 2002.

Penuelas, J., Filella, I., Stefanescu, C., and Llusia, J.: Caterpillars of Euphydryas aurinia (Lepidoptera: Nymphalidae) feeding on Succisa pratensis leaves induce large foliar emissions of methanol, New Phytol., 167, 851-857, 2005.

Rinne, H. J. I., Guenther, A. B., Warneke, C., de Gouw, J. A., and Luxembourg, S. L.: Disjunct eddy covariance technique for trace gas flux measurements, Geophys. Res. Lett., 28(16), 3139-3142, 2001.

Rinne, J., Taipale, R., Markkanen, T., Ruuskanen, T. M., Hellén, H., Kajos, M. K., Vesala, T., and Kulmala, M.: Hydrocarbon fluxes above a Scots pine forest canopy: measurements and modeling, Atmos. Chem. Phys., 7, 3361-3372, 2007, http://www.atmos-chem-phys.net/7/3361/2007/.

Schade, G. W. and Custer, T. G.: OVOC emissions from agricultural soil in northern Germany during the 2003 European heat wave, Atmos. Environ., 38, 6105-6114, 2004.

Schade, G. W. and Goldstein, A. H.: Seasonal measurements of acetone and methanol: Abundances and implications for atmospheric budgets, Global Biogeochem. Cy., 20, 2006.

Seufert, G., Bartzis, J., Bomboi, T., Ciccioli, P., Cieslik, S., Dlugi, R., Foster, P., Hewitt, C. N., Kesselmeier, J., Kotzias, D., Lenz, R., Manes, F., Perez Pastor, R., Steinbrecher, R., Torres, L., Valentini, R., and Versino, B.: An overview of the Castelporziano experiments, Atmos. Environ., 31(SI), 5-17, 1997.

Sillman, S.: The relation between ozone, $\mathrm{NO}_{\mathrm{x}}$ and hydrocarbons in urban and polluted rural environments, Atmos. Environ., 33, 1821-1845, 1999.

Simpson, D., Winiwarter, W., Borjesson, G.,Cinderby, S., Ferreiro, A. Guenther, A., Hewitt, C. N., Janson, R., Khalil, A., Owen, S., Pierce, T. E., Puxbaum, H., Shearer, M., Skiba, U., Steinbrecher, R., Tarrason, L., and Oquist, M. G.: Inventorying emissions from Nature in Europe, J. Geophys. Res., 104, 8113-8152, 1999.

Spirig, C., Neftel, A., Ammann, C., Dommen, J., Grabmer, W., Thielmann, A., Schaub, A., Beauchamp, J., Wisthaler, A., and Hansel, A.: Eddy covariance flux measurements of biogenic VOCS during echo 2003 using proton transfer reaction mass spectrometry, Atmos. Chem. Phys., 5, 465-481, 2005, http://www.atmos-chem-phys.net/5/465/2005/.

Staudt, M., Bertin, N., Hansen, U., Seufert, G., Ciccioli, P., Foster, P., Frenzel, B., and Fugit, J. L.: Seasonal and diurnal patterns of monoterpene emissions from Pinus Pinea (L) under field conditions, Atmos. Environ. 31(SI), 145-156, 1997.

Staudt, M. and Bertin, N.: Light and temperature dependence of the emission of cyclic and acyclic monoterpenes from Holm Oak (Quercus ilex 1.) leaves, Plant Cell Environ., 21, 385-395, 1998.

Street, R. A., Owen, S., Duckham, S. C., Boissard, C., and Hewitt, C. N.: Effect of habitat and age on variations in volatile organic compound (VOC) emissions from Quercus ilex and Pinus pinea, Atmos. Environ., 31(SI), 89-100, 1997.

Taipale, R., Ruuskanen, T. M., Rinne, J., Kajos, M. K., Hakola, H., Pohja, T., and Kulmala, M.: Technical Note: Quantitative long-term measurements of VOC concentrations by PTR-MS measurement, calibration, and volume mixing ratio calculation methods, Atmos. Chem. Phys., 8, 6681-6698, 2008, http://www.atmos-chem-phys.net/8/6681/2008/.

Tani, A., Hayward, S., and Hewitt, C. N.: Measurement of monoterpenes and related compounds by proton transfer reaction mass spectrometry, Int. J. Mass Spectrom., 223-224, 561-578, 2003.

Valentini, R., Greco, S., Seufert, G., Bertin, N., Ciccioli, P., Cecinato, A., Brancaleoni, E., and Frattoni, M.: Fluxes of biogenic VOC from Mediterranean vegetation by trap enrichment relaxed eddy accumulation, Atmos. Environ., 31(SI), 229-238, 1997.

Warneke, C., Luxembourg, S. L., de Gouw, J. A., Rinne, H. J. I., Guenther, A. B., and Fall, R.: Disjunct eddy covariance measurements of oxygenated volatile organic compounds fluxes from an alfalfa field before and after cutting, J. Geophys. Res., 107(D8), 4067, doi:10.1029/2001JD000594, 2002.

Wiberley, A. E., Linskey, A. R., Falbel, T. G., and Sharkey, T. D.: Development of the capacity for isoprene emission in kudzu, 
Plant Cell Environ., 28(7), 898-905, 2005.

Wilkinson, M. J.: Circadian control of isoprene emissions from oil palm. Ph.D. Thesis, Lancaster University, UK, 2006.
Zhao, J. and Zhang, R.: Proton transfer reaction rate constants between hydronium ion $\left(\mathrm{H}_{3} \mathrm{O}^{+}\right)$and volatile organic compounds, Atmos. Environ., 38, 2177-2185, 2004. 